\title{
Biopolitical Populism in Poland: The Case of PiS
}

\author{
Alexandra Yatsyk \\ Johan Skytte Institute of Political Studies, University of Tartu, Estonia \\ ayatsyk@gmail.com
}

\begin{abstract}
This paper examines the discourse of PiS party in Poland as a form of biopolitical populism. I view this phenomenon as a specific style of political discourse rather than an ideology, that, first, focuses on bodily issues, including family and gender policy, sexual behavior, etc., second - it is inherently performative and as such it appeals to emotions, and, third - it directly communicates with "people" while circumventing the existing institutional framework of the state. Based on the cases of PiS rhetoric on the Smolensk catastrophe, and its narratives on gender and anti-LGBTQ issues, I demonstrate how the latter could be used for political othering and for subverting the core democratic principles. My data includes publications in Polish media and on social platforms (Twitter and Facebook), mostly before and after elections to European and national parliaments in May and October 2019, as well as during the presidential election in spring $202 \mathrm{O}$.
\end{abstract}

\section{Keywords}

biopolitics - populism - Poland - LGBTQ - Smolensk catastrophe

In recent years, the scholarship on right-wing populism in Poland has brought into discussion its performative aspects as they relate to political elites, ${ }^{1}$ gender

1 Bartoszewicz, M. G. "Celebrity Populism: A Look at Poland and the Czech Republic." European Politics and Society, January ( 2019), 1-16; Paluchowski, W. J., Podemski, K. "Mowy miesięcznicowe Jarosława Kaczyńskiego jako spektakl władzy." Ruch Prawniczy, Ekonomiczny i Socjologiczny 4(2019), 253-268. 
and family, ${ }^{2}$ religion, ${ }^{3}$ or history. ${ }^{4}$ From a wider perspective of cultural studies, Polish right-wing populism is presented as a "thin-centered ideology", ${ }^{5}$ a sort of Durkheimian "magical thinking", ${ }^{6}$ a mythology, ${ }^{7}$ or a discursive "political

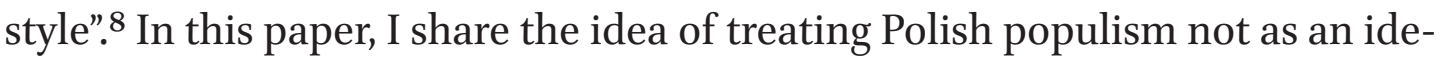
ology ${ }^{9}$, but as a discursive form, consisting of "the repertoire of performances that are used to create political relations.". ${ }^{10}$ In the words of Laclau, ${ }^{11}$ it is not

2 Korolczuk, E. '“The Purest Citizens' and 'IVF Children'. Reproductive Citizenship in Contemporary Poland." Reproductive Biomedicine and Society Online 3(2016),126-33; Żuk, P., and P. Żuk. "Murderers of the Unborn' and 'Sexual Degenerates': Analysis of the 'AntiGender' Discourse of the Catholic Church and the Nationalist Right in Poland." Critical Discourse Studies (2019). https://doi.org/10.1080/17405904.2019.1676808; Calkin, S., and M.E. Kaminska "Persistence and Change in Morality Policy: The Role of the Catholic Church in the Politics of Abortion in Ireland and Poland." Feminist Review 124 (1) (2020), 86-102; Mishtal, J. "Reproductive Governance and the (Re)Definition of Human Rights in Poland." Medical Anthropology 38 (2) (2019), 182-94; Mizielińska, J., and Stasińska, A. "There Is Nothing Like a Family': Discourses on Families of Choice in Poland." Journal of Homosexuality 64 (13) (2017), 1793-1815.

3 Stanley, B. "Defenders of the Cross: Populist Politics and Religion in Post-Communist Poland." In Saving the People: How Populists Hijack Religion, eds. McDonnell, D., Marzouki, N. and O.Roy (Oxford: Oxford University Press, 2016), 109-28; Jaskułowski, K. "W obronie krzyża. Rzecz o używaniu i nadużywaniu symboli w polityce." DYSKURs: Pismo Naukowo-Artystyczne ASP we Wrocławiu 16 (2013), 74-93.

4 Cadier, D., and K. Szulecki "Populism, Historical Discourse and Foreign Policy: The Case of Poland's Law and Justice Government." International Politics (2020). https://doi. org/10.1057/s41311-02O-oo252-6; Szeligowska, D. "Patriotism in Mourning." East European Politics \& Societies and Cultures 28 (3) (2014), 487-517; Zubrzycki, G. "The Politics of Jewish Absence in Contemporary Poland." Journal of Contemporary History $5_{2}^{2}$ (2) (2016), 250-77; Hackmann, J. "Defending the 'Good Name' of the Polish Nation: Politics of History as a Battlefield in Poland, 2015-18." Journal of Genocide Research 20 (4) (2018), 587-606.

$5 \quad$ Mudde, C. Populist Radical Right Parties in Europe (New York: Cambridge University Pressm, 2007); Kotwas, M., and J.Kubik "Symbolic Thickening of Public Culture and the Rise of Right-Wing Populism in Poland." East European Politics and Societies 33 (2) (2019), 435-71; Waligórska, M. "On the Genealogy of the Symbol of the Cross in the Polish Political Imagination." East European Politics and Societies 33 (2) (2019), 497-521.

6 Jaskułowski, K. Op. cit.

7 Futyra, M. “Od Rzeczypospolitej szlacheckiej do IV RP. Krótki przegląd polskiej mitologii założycielskiej.” Sprawy Narodowościowe. Seria nowa, (2017). https://doi.org/10.11649/ sn.1324; Niżyńska, J. "The Politics of Mourning and the Crisis of Poland's Symbolic Language after April 10." East European Politics and Societies 24 (4) (2010), 467-479.

8 Cadier, D., and K. Szulecki, K. Op.cit.

9 "Zizek: Only a pan-European left can defat 'populism", RT, June 2 (2019), https:// www.rt.com/op-ed/46o89o-zizek-eu-electionsleft/?fbclid=IwAR3tJ78ZM OVFr4xIvQ9SUY2nppH3NZewU3aNw8o8f9JSb7 $\mathrm{IXrBIJV}_{5} \mathrm{Z}_{5}$ ao.

10 Moffitt, B., and S. Tormey "Rethinking Populism: Politics, Mediatisation and Political Style." Political Studies 62(2) (2014), p. 387.

11 Laclau, E. On Populist Reason (Reprint ed. London: Verso, 2005). 
the content but the form that makes the rhetoric populist. According to this approach, the populist logic is characterized by the building of the "chains of equivalency"12 between people's demands and "creation of an internal frontier dichotomizing the social". ${ }^{13}$ It entails not only expressing the opposing identities, but also constructing them under the categories of "the others" (aliens, enemies, strangers) and "the people" (members of "we-community").

This point is a key for political discourse, which explains my qualification of Polish populism as biopolitical. In the field of Foucauldian studies biopolitics presupposes the aggregation of population into a single collective body through disciplinary practices of controlling and regulating individual human lives. ${ }^{14}$ It implies management of health, hygiene, nutrition, birth, sexuality, patterns of consumption, mobility and travel, medicalization, etc. Biopolitics does not only correspond with regulating the allegedly (pre)existing populations, but also might be part of nation-building, a subjectifying force that produces various collective identities and biopolitical communities (gender, national, religious, etc.). In contrast to mainstream literature on populism, which typically looks at it as a series of direct appeals to the people, or population, or electorate that circumvent the existing bureaucratic institutions and aim against the ruling elites, populism understood within the biopolitical approach is a technology implying the (re)construction and (re)institution of people through hierarchization of different "forms of life". ${ }^{15}$ This technology not only distinguishes "people" from "the elite", but it includes an important divide between authentic and fully-fledged "people" (the "majority"), on the one hand, and those groups that are not consensually considered as legitimately belonging to the national political community-in-the-making (different minorities). Seen from this perspective, biopoliticization of populism might take radical forms of exclusion, denial of belonging and even de-humanization.

Since 2015, when the Prawo i Sprawiedliwość (PiS, Law and Justice) party came to power in Poland, it started to pursue conservative policy agenda, which included measures aimed at restricting the rights of women and members of LG BT community, undermining the freedom of speech and weakening the independence of judiciary. There are many illustrative examples of such

\footnotetext{
12 Ibid.

13 Cadier, D., and K. Szulecki, K. Op. cit.

14 Foucault, M. Security, Territory, Population: Lectures at the Collège De France 1977-1978. (New York: Picador, 2009).

15 DeCaroli, S. "What Is a Form of Life? Giorgio Agamben and the Practice of Poverty." In Agamben and Radical Politics, eds. D. McLaughlin (Edinburg: Edinburg University Press, 2017), 207-233, Ferrarese, E. “The use of bodies. Agamben's idea of a non-capitalist form of life," Journal for Cultural Research 22 (2) (2018), 126-136.
} 
measures, including the so called "small media law" that came into force in 2016, allowing PiS to control public media; ${ }^{16}$ legislative amendments targeting the judiciary in 2018-2019; the "anti-abortion" law aiming to ban abortions; and the law seeking to criminalize sexual education of minors debated by the Polish Parliament in spring 2020. EU considers all of them as serious violations of liberal democratic principles and the rule of law. ${ }^{17}$

For PiS the imposition of traditional and religious values in the areas of immigration, gender policy and education means protection of the nation's societal and ontological security from external threats. I consider this regime of power both conservative and biopolitical, ${ }^{18}$ because it extensively controls and fosters the population through disciplining bodies when it comes to sexuality, reproduction, life styles, etc. from the perspective of traditional and religious values. For the state as a biopolitical actor, human bodies - whether they are alive, dead, disabled or unborn - are sources of its power. As parts of the national political body, they should be classified and grouped depending on different "forms of life", ${ }^{19}$ which the state or other biopolitical actors (the church, NGOS, social movement, etc.) consider either "normal" or deviant. Diverse forms of biopolitical othering aim at indicating "whether certain life is worthy of living", ${ }^{20}$ and in extreme cases displays "the "killability' of those who ... are abandoned by the norm". ${ }^{21}$ PiS as a ruling party has been steadily incorporating the practice of biopolitical othering into domestic policy, as represented by the programme " $500+$ ", geared towards increasing the birth rate among Polish citizens, or a bill proposing total ban on abortions and prohibition of sexual education at schools.

16 Głowacka, D. "Public media reform in Poland—a political takeover?" Helsinki Foundation for Human Rights, June 30, 2016, https://www.uni-muenster.de/Jura.tkr/oer/files/pdf/ workshops/2016/impact_on_media_systems/Glowacka.pdf.

17 Santora, M. "Poland's Populists Pick a New Top Enemy: Gay People." New York Times, April 7, 2019, https://www. nytimes.com/2019/o4/o7/world/europe/poland-gay-rights.ht ml?fbclid=IwARoPPvRLVjp 7 KOKLM.

F6OtlMbMDu1 ocubuLZwDHgVTeqIFNMCYbbAvuuVUbM; Wądołowska, A. (2020) "Polish towns denied EU funding due to 'LGBT ideology free zones," Notes from Poland, July 29, https://notesfrompoland.com/2020/07/29/polish-towns-denied-eu-fundingdue-to-lgbt-ideology-free-zones/.

18 Foucault, M. Security, Territory, Population: Lectures at the Collège De France 1977-1978 (New York: Picador, 2009).

19 Agamben, G. Means without Ends. Notes on Politics (Minneapolis and London: University of Minnesota Press, 2000).

$20 \quad$ Vaughan-Williams, N. "The generalised bio-political border? Re-conceptualising the limits of sovereign power," Review of International Studies 35(04) (2009), p. 746

21 Minca, C. "Agamben's geographies of modernity," Political Geography 26 (1) (2007), p. 88. 
In this paper I examine the discourse of PiS in Poland as a form of biopolitical populism and a performative phenomenon. To develop this argument, I focus on PiS initiatives towards LGBTQ and family policy in 2016-202O and its narrative about the Smolensk tragedy. My empirical data includes publications in Polish open sources (representing both liberal and conservative narratives) and on social media platforms (Twitter and Facebook), mostly before and after elections to European and national parliaments in May and October 2019 respectively, as well as during the presidential election in spring 2020. ${ }^{22}$

PiS Performative Populism Explores the "Smolensk Catastrophe"

On April 10, 2010, the Polish government plane carrying the high-ranking state delegation, which included the representatives of Polish political and military elite, crashed near Smolensk in Russia. All 96 people on board, including the then-President Lech Kaczyński and his wife, the former President of Poland in exile Ryszard Kaczorowski, the Chief of General Staff and others, who were flying to Russia to participate in the ceremony marking the $70^{\text {th }}$ anniversary of the Katyn massacre, perished in the crash. The tragedy shocked Polish society and raised many questions about what caused the tragic air disaster. The late President Kaczyński's twin-brother, Jarosław, from the outset used the Smolensk tragedy to consolidate political power under PiS. ${ }^{23}$

During the national parliamentary election campaign in 2015, PiS and its supporters actively discussed the Smolensk catastrophe as a tragic manifestation of "Poland in ruins" and used this narrative "as an axiological and symbolic basis for criticizing the state: its weakness first contributed to the catastrophe... and then made it impossible to explain its causes". ${ }^{24}$ According to

22 In particular, I analyze the following sources in 2018-2020: 1) Polish media (both independent and pro-PiS), including Gazeta Wyborcza, Rzeczpospolita, Dziennik, TVP Info (Telewizja Polska), Wprost, Onet, Notes from Poland, etc.; 2) official websites, facebook and twitter accounts of PiS' representatives (including @pisorgpl, @AndrzejDuda, @MorawieckiM, @PremierRP, @BeataSzydło) and its liberal opponents (@donaldtuskEPP, @Platforma_org, @trzaskowski, etc.);3) posts on Twitter with hashtags \#SmoleńskPamiętamy, \#KatastrofaSmoleńska, etc., 4) posts on Twitter by Polish LGBTQ activists and groups (@strajkkobiet, etc.) and their conservative opponents (@Prawo_do_ zycia, etc.).

23 Paluchowski, W. J. and K. Podemski "Mowy miesięcznicowe Jarosława Kaczyńskiego jako spektakl władzy," Ruch Prawniczy, Ekonomiczny i Socjologiczny 4 (2019), 253-268.

24 Nyzio, A. "Znacząca nieobecność? Katastrofa smoleńska w kampaniach wyborczych 2015 roku." In Oblicza kampanii wyborczych 2015 roku, eds. M.Kułakowska, P. Borowiec, and P. Ścigaj (Kraków, 2016), 435-436. 
PiS, both investigative reports produced by the Interstate Aviation Committee of the Commonwealth of Independent States and the Polish Committee for Investigation of National Aviation Accidents (Komisja Badania Wypadków Lotniczych Lotnictwa Państwowego; KBWLLP), which in 2011 was headed by the then-Minister of Interior Jerzy Miller, were deemed inadequate. These reports did not support PiS version of the catastrophe that stemmed from a conspiracy theory according to which Donald Tusk's government colluded with Russian intelligence service to plant explosives on the aircraft, which caused its explosion in the air. ${ }^{25}$ Polish liberal opposition, in turn, accused PiS investigative committee of wasting taxpayers' money. ${ }^{26}$

Analysis of the Smolensk catastrophe as a political performance and a part of Polish national mythology ${ }^{27}$ demonstrates that the "cult of Smolensk" was created and promoted by PiS and its supporters, including the Polish Catholic Church, pro-PiS media and social organizations (such as "Solidarni 2010"28), as a mix of religious and commemorative rituals, ${ }^{29}$ conspiracy theories ${ }^{30}$ and the rhetoric of "finding the truth". ${ }^{31}$ Paluchowski and Podemski in their study of Jarosław Kaczyński's speeches commemorating the Smolensk catastrophe from 2010 to 2018 demonstrate that the idea of "searching for the truth" about the Smolensk tragedy was repetitively infused with the ideas of Polish authenticity. ${ }^{32}$ For PiS, "the fight for the truth" was considered as one of the most important Polish endeavors, along with discussions on "communism versus anti-communism, Euro-enthusiasm versus Euroscepticism, and liberalism versus solidarity". ${ }^{33}$ In fact, the debate on the Smolensk catastrophe replaced

25 Wiezejski, A. "Macierewicz: Rosjanie usiłowali uczynić z brzozy symbol dramatu smoleńskiego," Telewizja Republika "FAKTY”, April 17, 2020, https://telewizjarepublika.pl/ macierewicz-rosjanie-usilowali-uczynic-z-brzozy-symbol-dramatu-smolenskiego,94521 .html.

26 "Dwa wybuchy, ślady trotylu'. Ustalenia podkomisji smoleńskiej," Polsat News, July 3o, 2020, https://www.polsatnews.pl/wiadomosc/2020-07-30/dwa-wybuchy-slady-trotyluustalenia-podkomisji-smolenskiej/.

27 Futyra, M. Op.cit.; Niżyńska, J. Op.cit.

28 "Stowarzyszenie Solidarni.2010," http://solidarni2010.pl, accessed September 2, 2020.

29 Jaskułowski, K. Op.cit.; Szeligowska, D. Op.cit.; Zubrzycki, G. "Polish Mythology and the Traps of Messianic Martyrology." In National Myths: Constructed Pasts, Contested Presents, ed. G.Bouchard (London, New York: Routledge, 2013) 110-132; Stanley, B. Op.cit.

$30 \quad$ Nyzio, A. Op. cit.

31 Paluchowski, W. J. and K. Podemski. Op. cit.

32 Ibid., 296.

33 Nyzio, A. Op. cit., p. 439. 
technocratic approach to politics with populist rhetoric, ${ }^{34}$ extending beyond mere political competition to the sphere of politicized art and language. ${ }^{35}$

According to Stanley and Cześnik, PiS populist strategy could be considered the "performance of crisis", ${ }^{36}$ and it has been unfolding as a "set of discursive actions that produce and perpetuate the experience of crisis, the deepening of which can then be used to justify further actions". ${ }^{37}$ Since 2015, PiS has been deliberately employing the performative model, identifying itself with "ordinary people" facing the "crisis". Its rhetoric contained appeals to three types of "crisis": political (corruption and state capture), economic (exclusion of certain social groups from economic benefits), and cultural (insufficient state's protection of the "authentic" Polish values and identity from "amoral and ahistorical nebulousness of cosmopolitanism"). ${ }^{38}$

Post-communist liberal elites, including those from the Solidarnośc movement such as Lech Wałęsa or members of Platforma Obywatelska (PO) with whom PiS once had common roots in the past, were declared responsible for the "crises" and for the "systemic pathology" that explains the distorted democratization. ${ }^{39}$ PiS has promised to "fix" the system, which is lucidly exemplified by deep transformations in the understanding of freedom of speech, as well as by judiciary reform and gender policies pursued in 2016-2020. However, PiS discourse about the Smolensk tragedy can also be understood as one of the pillars of the populist performative "crisis" model, which has biopolitical (or, rather-necropolitical) references at its core.

According to PiS and its supporters, President Kaczyński "died as a hero" and this was the reason to bury him and his wife at Polish national pantheon in the Wawel castle in Cracow, where Polish monarchs, national heroes and poets have been laid to rest. ${ }^{40}$ In the context of PiS narrative, it was not Kaczyński's life or presidency that made him worthy of a royal burial, but his death in proximity to Katyń, a symbol of Polish martyrdom, where in 1941, 22,00o Polish officers were summarily executed by Stalin's secret police (NKVD). ${ }^{41}$ Thus,

$34 \quad$ Ibid., 144.

35 Ibid., 439-440.

36 Moffitt, B., and S. Tormey. Op. cit.

37 Stanley, A., and M. Cześnik "Populism in Poland." In Populism around the World: A Comparative Perspective, eds. D. Stockemer (Cham: Springer, 2019), p. 79.

38 Ibid.

39 Ibid.

40 "Dziwisz: to nie ja proponowałem Wawel," Wprost, April 10, 2010, https://www.wprost .pl/192537/dziwisz-to-nie-ja-proponowalem-wawel.html.

41 Zubrzycki, G. "Polish Mythology and the Traps of Messianic Martyrology." In National Myths: Constructed Pasts, Contested Presents, ed. G. Bouchard, (London, New York: Routledge, 2013), p. 110. 
President Kaczyński's dead body became an essential part of Polish conservative necropolitics, which refers to the "paradigmatic principle of rule that differentiates among, and capitalizes on, the imposition of various forms of death"42. Following the necropolitical logic, the biopolitical border between "real patriots" of Poland and "untrue Poles" or even "traitors" corresponds with the difference between those who participated in "martyrologic-patriotic race"43 dedicated to the dead President, and those who abstained from it or criticized it. ${ }^{44}$ This "race" was a highly performative set of actions and included monthly religious liturgies, torch marches, media events, and public clashes (between the so-called "defenders of the cross", who in 2010 erected a cross near the Presidential Palace in Warsaw to commemorate the victims of the Smolensk tragedy, and their opponents ). PiS idea to turn the death of President Kaczyński into a new symbol of Polish "martirological messianism" 45 culminated in the installation of two monuments to Lech Kaczyński and other politicians, who perished in the Smolensk plane crash, on Warsaw's central Piłsudski Square. Both monuments were unveiled in 2018, the year of centenary anniversary of the Polish independence. Standing in close proximity to the statue of the founder of Polish state Marshal Józef Piłsudski, a cross dedicated to the visit of Pope John Paul II to Warsaw in 1979, and a Tomb of Unknown Soldier, they all symbolize the most important tenets of the Polish national identity according to the dominant Polish discourse.

The analysis of Polish media, including posts on Twitter in 2018-2020, demonstrates that the "ordinary people," politicians and public figures discussed the Smolensk tragedy in the context of PiS populist rhetoric rather than as a symbol of national mourning. In the words of Lech Wałęsa, the Polish President in 1990-1995 and currently an active opponent of PiS, the responsibility for the Smolensk catastrophe lies with Jaroslaw Kaczyński, "who has so many broken rights and rules on his conscience that he actually has no choice. That's why he will set the country on fire to save himself. Responsibility for the Smolensk disaster should be settled".46

\footnotetext{
42 Gržinić, M., and Š. Tatlić. Necropolitics, Racialization, and Global Capitalism:Historicization of Biopolitics and Forensics of Politics, Art, and Life (Lanham: Lexington Books, 2014), p. 2.

43 Szeligowska, D. "Patriotism in Mourning." East European Politics \& Societies and Cultures 28 (3) (2014), p. 498.

44 Jaskułowski, K. Op.cit.

45 Zubrzycki, G. "The Politics of Jewish Absence in Contemporary Poland." Journal of Contemporary History $5^{2}$ (2) (2016), 250-277.

46 "Lech Walęsa. Facebook profile", Facebook, April 20, 2020, https://www.facebook.com/ lechwalesa/.
} 
The pandemic caused by the Covid-19 pandemic brought the biopolitical agenda to the forefront of political debates in the country in 2020. In this regard some liberal circles used the Smolensk tragedy as a metaphor, compared the world battered by the pandemic with that faulty aircraft that is now "flying towards a birch". ${ }^{7}$

\section{2 \\ PiS Biopolitical Conservatism in 2016-2020}

The "500+" programme was introduced by PiS in 2016, to support families with more than one minor child through monthly allowance in the amount of 500 PLN or approximately 110 EUR. However, in the words of PiS MP Krystyna Pawłowicz, this initiative did not extend to non-Polish citizens because it was intended "to improve the demographic situation of Poland, not that of other nations". 48 Similarly, the law on adoption passed in 2017 imposed certain restrictions on foreigners. As a result, the total number of adoptions in Poland decreased by more than a half already in 2017 and more children stayed in orphanages instead of being adopted by families. ${ }^{49}$

PiS practice of selectively banning the rights of biopolitical "others" for the sake of "protecting" those, who are considered "ours," is a form of populism in power that could be lucidly demonstrated by the so called "anti-abortion law". Since 1993 Poland has been enforcing one of the strictest anti-abortion legislations in the EU. It mandates that the termination of pregnancy is allowed only when not doing so could pose serious health risks for mothers. Other exceptions include instances of rape or incest, or when a fetus is severely and inoperably damaged.$^{50}$ In 2016 Polish conservative establishment, including the President Andrzej Duda, Prime Minister Beata Szydło, Senate Speaker Stanisław Karczewski, Science Minister Jarosław Gowin, and others supported the idea of total ban on abortions and introduction of criminal penalty of up to

47 Żakowski, J. “Nasz świat leci na brzozę. Pull up!”, Wyborcza, April 9, 202o, https://wyborcza .pl/7,75968,25854815,nasz-swiat-leci-na-brzoze-pull-up.html.

48 Nałęcz, M. "Krystyna Pawłowicz Nie Dowierza, Że 50o Plus Dostają Cudzoziemcy. 'To Chyba Nieprawda." Wiadomości, June 20, 2018, https://wiadomosci.wp.pl/krystynapawlowicz-nie-dowierza-ze-5oo-plus-dostaja-cudzoziemcy-to-chyba-nieprawda6264835261675649a.

49 "Foreign Adoptions in Decline in Poland," RadioPoland, June 25, 2018. http://thenews .pl/1/11/Artykul/369869,Foreign-adoptions-in-decline-in-Poland.

50 "Deadline for Signatures under Proposed Anti-Abortion Laws." Radio Poland, November 20, 2017, http://www.thenews.pl/1/9/Artykul/33591o,Deadline-for-signatures-under-proposedantiabortion-laws. 
5 years in prison for both women and doctors regardless of the circumstances. ${ }^{51}$ The law failed to pass because of the significant public backlash, which manifested in large number of protests across the country. ${ }^{52}$ However, some prominent members of the Catholic clerical establishment and ultra-conservative activists continue their lobbying activities in support of this law. ${ }^{53}$

In April 2020, the Polish legislature of new convocation, where PiS continues to maintain parliamentary majority, included the discussion of the antiabortion law in the legislative agenda. ${ }^{54}$ In the words of President Duda, he does not support abortions even when fetuses have severe and irreversible congenital defects because doing so would be "eugenic" and it is a "murder" to "kill disabled children".55 This sentiment echoes that of the chairman of ruling PiS party, Jarosław Kaczyński, who stated in 2018 that his party would "strive to ensure that even very difficult pregnancies, when the child is likely to die, or is severely deformed, should not be terminated, so that the child can be christened, buried, and given a name". ${ }^{56}$ From PiS biopolitically conservative perspective, the unborn children are a form of Agambenian "bare life"57 and as such they represent a biopolitical community, ${ }^{58}$ which should be prioritized over those women, who choose to manage their own bodies and thus pretend to be subjects rather than objects of political control.

51 Domonoske, C. "Polish Women Hold 'black Monday' Strike to Protest Proposed Abortion Ban." NPR, October 4, 2016, https://www.npr.org/sections/thetwo-way/2016/10/o4/ 496526o99/polish-women-hold-black-monday-strike-to-protest-proposed-abortion-ban.

52 Lempart, M. "Bishops in Poland Demand a Ban on Abortion: Government Bows down and Complies! Polish Women's Strike Respond." Polish Women's Strike, March 20, 2018, http://www.safeabortionwomensright.org/poland-bishops-in-poland-demand-a-ban-onabortion-government-bows-down-and-complies-polish-womens-strike-respond/.

53 Rogaska, K. "Coraz Trudniej O Legalną Aborcję. Szpitale Odmawiają Wykonywania Zabiegów." Onet, April 4, 2019, https://kobieta.onet.pl/coraz-trudniej-o-legalna-aborcjeszpitale-odmawiaja-wykonywania-zabiegow/61ts5xq.

54 "Projekty zakazujące aborcji i edukacji seksualnej skierowane do komisji. Strajk Kobiet: 'Niech tam zamarzną na wieki,', Gazeta Wyborcza, April 16, 2020, https://wroclaw.wyborcza .pl/wroclaw/7,35771,25875539,sukces-polek-po-strajkach-sejm-wstrzymal-glosowanie-nadzakazem.html.

55 Wilczek, M. "As abortion ban returns to parliament, Polish women find ways to protest amid lockdown," Notes of Poland, April 14, 2020, https://notesfrompoland.com/2020/ 04/14/as-abortion-ban-returns-to-parliament-polish-women-find-ways-to-protest-amidlockdown/.

56 Ibid.

57 Agamben, G. Means without Ends. Notes on Politics (Minneapolis and London: University of Minnesota Press, 2000).

58 Makarychev, A., Yatsyk, A. Critical Biopolitics of the Post-Soviet: From Populations to Nations (Lexington Books, 2019). 
The resumption of parliamentary debates on anti-abortion law was accompanied by the large-scale protests despite the restrictions on public gatherings due to Covid-19. ${ }^{59}$ In response, the supporters of the law - the Polish Catholic Church and a number of ultra-conservative organizations, such as the Small Feet Foundation (Fundację Matych Stópek) and the initiator of "anti-sex education" and "anti-abortion" laws Pro-Right to Life Foundation (Fundacji Pro-Prawo do Życia) — organized marches "for life", the signature campaign "Stop abortion" (Zatrzymaj aborcję) ${ }^{60}$ and Twitter campaign under the \#FalaŻycia hashtag. ${ }^{61}$

PiS MP Mirosława Stachowiak-Różecka thinks that re-submission of the anti-abortion law for parliamentary consideration reflects the "will of ordinary people" that her party "can't simply ignore." ${ }^{\prime 2}$ In its discussions on the subject, PiS has actively used the populist method of solidarization with the "ordinary people" against the "others" despite the fact that, as demonstrated by the IPsos survey conducted in 2018, only 11 percent of Poland's residents support stricter abortion rules, while 38 percent prefer their liberalization. ${ }^{63}$

From the perspective of biopolitical conservatism, easing the Polish abortion law does not correspond with the "genuine" democracy and protection of life. On the contrary, according to PiS, to allow women to decide whether a fetus will live or die means delegating them the sovereign power that should belong only to the state and the church.

In the words of the Ordo Iuris Institute for Legal Culture, a conservative profamily advocacy group, the "anti-abortion law"

is not only fully compliant with the Polish Constitution and international law, which is in force in Poland, but it also repeals legal provisions which are incompatible with the Polish Constitution. The Constitution of the

59 Organized, for instance by Ogólnopolski Strajk Kobiet, a pro-feminist movement (\#PiekłoKobiet \#PolskiePiekło \#StrajkKobiet).

6o “Strona życia," official web page 'Right for life' Foundation," accessed September 14, 2020, https://stronazycia.pl/stop-aborcji/.

61 the \#FalaŻycia action encourages Poles to tell stories about their children who might not have been born if the abortion law was soften in Poland, see https://twitter.com/ falazycia?lang=en.

62 Stachowiak-Różecka, M. "To projekt obywatelski, którym musimy się zająć." Poseł PiS o zmianie prawa antyaborcyjnego", Polskie Radio 24, April 14, 2020, https://www.polskieradio 24.pl/130/5553/Artykul/2492006,To-projekt-obywatelski-ktorym-musimy-sie-zajac-PoselPiS-o-zmianie-prawa-antyaborcyjnego.

63 Wilczek, M. "As abortion ban returns to parliament, Polish women find ways to protest amid lockdown", Notes from Poland, April 14, 2020, https://notesfrompoland.com/ 2020/04/14/as-abortion-ban-returns-to-parliament-polish-women-find-ways-to-protestamid-lockdown/. 
Republic of Poland guarantees protection of life of every human being and does not make this protection dependent on age (which includes irrelevance of whether one has already been born or not), health condition or life expectancy. Moreover, it imposes supporting the disabled (regardless of age) and forbids discrimination based on age or health condition. Eugenic abortion violates all of the above-mentioned resolutions of the Constitution...no international treaty obliges Poland to legitimize abortion in any respect. ${ }^{64}$

Following this rationale, there are others, including the international representatives of the UN committees, who are interested in decreasing the "standards of life protection and promote the ideological concept of 'reproductive rights' - contrary to international agreements which protect human rights. Their actions, however, are deemed illegitimate and deprived of any legal force". ${ }^{65}$ In other words, from the perspective of the biopolitically conservative populism, the discussion on "anti-abortion" law by PiS and its supporters could be understood as an attempt to resignify such "floating signifiers" 66 as "human rights", "common good", or "democracy". For PiS, the anti-abortion issue is not a debate about freedom of managing one's own body, but an issue of reproductive versus human rights where the latter must prevail for the sake of a "common good".

In April 2020, the Polish parliament commenced discussions of another conservative initiative. The foundation Pro-Prawo do Życia [Right to Life] submitted for Sejm's consideration what is unofficially known as the "Stop pedofilia" (Stop pedophilia) initiative. It entails fines, restriction of freedom or imprisonment for up to three years for those who "propagate or approve of engagement by minors in sexual intercourse or other sexual activity" while "performing activities related to upbringing, education, health care or care of minors", ${ }^{67}$ including school education. ${ }^{68}$ This bill is the result of intense antiLGBTQ debate between PiS and its liberal opponents during the 2019 electoral

64 "Eugenic abortion unconstitutional and against international law-Ordo Iuris submits opinion to MPs", Ordo Iuris official web page, April 14, 2020, http://en.ordoiuris.pl/lifeprotection/eugenic-abortion-unconstitutional-and-against-international-law-ordo-iurissubmits.

65 Ibid.

66 Laclau, E. Op. cit.

67 Wilczek, M. Op. cit.

68 "Inicjatywa 'Stop pedofilii' w Sejmie. Projekt skierowany do komisji," PolskieRadio24, April 16, 2020, https://www.polskieradio24.pl/5/1222/Artykul/2493076,Inicjatywa-Stoppedofilii-w-Sejmie-Projekt-skierowany-do-komisji. 
campaigns for the European and national parliaments. In February 2019 the Warsaw mayor Rafał Trzaskowski, a member of opposition Civil Coalition (PO) and the key opponent of Duda in the 2020 presidential elections, adopted the so-called urban policy for LGBT+ communities. It consisted of the introduction of LGBTQ-friendly anti-discrimination policy towards sex education in schools, "taking into account the issues of psychosexual identity and gender identification, in accordance with the standards and guidelines of the World Health Organization (wHO)". ${ }^{69}$ Also in February 2019 another representative of liberal political forces, former MP and prominent LGBTQ activist Robert Biedroń established a pro-LGBTQ Wiosna (Spring) party.

In response, PiS and President Duda accused LGBTQ community of spreading an "evil ideology"70 leading to children's early sexualization and erosion of the traditional family model. ${ }^{71}$ Some influential representatives of the Polish Catholic Church also actively contributed to anti-LG BTQ discourse, referring to the gay community as a "rainbow plague", similarly to the "red plague" of Bolshevism. ${ }^{72}$

Despite the obvious misinterpretation of Trzaskowski's declaration, ${ }^{73} \mathrm{PiS}$ scapegoating rhetoric was actively supported by some Polish municipalities, which declared themselves zones free from LG BT "ideology". ${ }^{44}$ A number of

69 Trzaskowski, R. "Deklaracja Warszawska Polityka miejska na rzecz społeczności LGBT+", February, 18, 2019, p. 3, https://mnw.org.pl/app/uploads/2019/o2/warszawska-deklaracjalgbt.pdf.

70 Tilles, D. "Polish president condemns LGBT "ideology of evil" in new speech as EU Commissioner issues criticism", Notes from Poland, June 15, 2020, https://notesfrompoland .com/2020/o6/15/polish-president-condemns-lgbt-ideology-of-evil-in-new-speech-as-eucommissioner-issues-criticism/.

71 Pacewicz, P., and A. Ambroziak "Kaczyński do LGBT: 'WARA od naszych dzieci!' I kto to mówi?", oko.press, March 16, 2019, https://oko.press/kaczynski-do-lgbt-wara-od-naszychdzieci-i-kto-to-mowi/; Sitnicka, D. "Przedszkolaki zmuszane do masturbacji? Zobacz, co jest faktem, a co fantazją o Deklaracji LGBT,” o Ko.press, March 11, 2019, https://oko. press/przedszkolaki-zmuszane-do-masturbacji-zobacz-co-jest-faktem-a-co-fantazjaw-deklaracji-lgbt/; Tilles, D. "Polish president proposes constitutional ban on same-sex adoption, calling it 'enslavement' “, Notes from Poland July 4, 2020, https://notesfrompoland.com/2020/07/04/polish-president-proposes-constitutional-ban-on-same-sexadoption-calling-it-enslavement/.

72 "Abp Jędraszewski na mszy z okazji rocznicy Powstania: Czerwonej zarazy już nie ma, ale jest nowa, tęczowa," Wiadomości, August, 1, 2020, https://wiadomosci.gazeta.pl/ wiadomosci/7,114883,2505०520,abp-jedraszewski-na-mszy-z-okazji-rocznicy-powstaniaczerwonej.html.

73 Trzaskowski, R. FaceBook page, February 18, 2019, https://www.facebook.com/rafal .trzaskowski/posts/10156879904986o91.

74 "Atlas of Hate," accessed September 2, 2020, https://atlasnienawisci.pl; "Powiat Rycki wolny od ideologii gender i 'LGBT', Powiat Rycki official webpage, April 30, 2019, https:// 
anti-LG BTQ resolutions peaked during political campaigning for the European and the national parliamentary elections in spring and summer 2019. According to the "Map of Hate" (Atlas Nienawiśći), created by the LG BTQ activists, about 100 municipalities, mostly located in southern Poland, declared themselves "LGBT-free zones". ${ }^{75}$ Rising anti-LGBTQ sentiments in public resulted in violent incidents targeting LG BTQ community at gay pride parades and "pro-family" marches that took place in Białystok, Lublin, Plock, Cracow (Kraków) and other Polish cities. ${ }^{76}$ The EU expressed concern about the situation, pointing to the discrimination of minorities and the violations of the principles of democracy. Brussels also withdrew funds allocated earlier for those municipalities that proclaimed themselves LG BTQ free zones. ${ }^{77}$

In the international LGBTQ advocacy group International Lesbian, Gay, Bisexual, Trans and Intersex Association's (ILGA Europe) annual ranking (Rainbow Europe) of European countries with regard to having LG BTQ-friendly policies, Poland has the lowest score among EU member-states in 2020. In comparison with 2017 , the degree of homophobia in the country increased. ${ }^{78}$ However, as the IPSOs survey conducted in Poland in February 2019 shows, $5^{6}$ percent from 1,009 respondents accepted the same-sex unregistered partnership and 41 percent recognized the possibility of gay marriage. The percentage of those who accepted adoption of children by LGBTQ couples was more modest, however, at 18 percent, while those, who opposed, constituted 77 percent. Interestingly, even among the progressive electorate of the LGBTQfriendly Wiosna party the share of supporters of the adoption of children by gay couples barely exceeded half (53 percent). Among PiS voters only 3 percent considered this appropriate. ${ }^{79}$ Quite predictably, the majority of PiS electorate was also unfavorable towards same-sex partnerships ( 67 percent "against" vs.

\footnotetext{
www.ryki.powiat.pl/aktualnosci/n,70753,powiat-rycki-wolny-od-ideologii-gender-i-lgbt .html\#.

75 "Atlas of Hate," https://atlasnienawisci.pl.

76 "In Poland, simmering anti-LGBTQ sentiment boils over into violence", PBs NewsHour, YouTube, July 22, 2019, https://www.youtube.com/watch?v=Tpc6fWburAo.

77 Wądołowska, A. "Polish towns denied EU funding due to 'LGBT ideology free zones', Notes from Poland, July 29, 2020, https://notesfrompoland.com/2020/07/29/polishtowns-denied-eu-funding-due-to-lgbt-ideology-free-zones/.

78 Ambroziak, A. "Porażka. Polska drugim najbardziej homofobicznym i transfobicznym krajem UE. 2 mln obywateli i obywatelek wciąż bez prawnej ochrony," OKO.press, May 14, 2018, https://oko.press/porazka-polska-drugim-najbardziej-homofobicznym-itransfobicznym-krajem-ue-2-mln-obywateli-i-obywatelek-wciaz-bez-prawnej-ochrony/.

79 Ambroziak, A. "Rekordowe poparcie dla związków partnerskich i równości małżeńskiej", OKO.press, February 25, 2019, https://oko.press/rekordowe-poparcie-dla-zwiazkowpartnerskich-i-rownosci-malzenskiej-sondaz/.
} 
28 percent "for", correspondingly). ${ }^{80}$ The 2019 survey by the US think tank Pew Research Center revealed a decreasing level of tolerance towards homosexuality in Poland as well as the deep split in society: 42 percent of respondents thought that homosexuality should not be accepted by the Polish society, while 47 percent accepted it. ${ }^{81}$

The consistently harsh anti-LG BTQ rhetoric might allow PiS to attract new supporters and to expand its support base. As PiS aggressive populist campaign against refugees in 2015 demonstrated, it is possible to significantly change the social attitudes in a relatively short period of time. From May 2015 to April 2016, the number of people, who were against accommodating refugees, increased threefold from 21 to 61 percent. ${ }^{82}$

Thus, in the framework of PiS populism by the time of elections in 2019, the anti-refugee campaign was replaced with the anti-LGBTQ messages, which implies that from the biopolitical perspective, both represent a generalized biopolitical "other." But Polish conservatives have other targets in sight as well, including veganism and environmental activism, ${ }^{83}$ which demonstrates that the biopolitical bordering continues to play a decisive role in Polish populism.

\section{Conclusion}

In this paper I have laid out the argument that PiS policies and rhetoric since 2010 could be understood as a form of biopolitical populism. I view this phenomenon as a specific style of political discourse rather than an ideology, that, first, focuses on bodily issues, including family and gender policy, sexual behavior, live styles, sexual education in schools, etc., second-it is inherently performative and as such it appeals to emotions, and, third - it directly

\footnotetext{
$80 \quad$ Ibid.

81 Tilles, D. "Under half of Poles say homosexuality should be accepted but figure rising, finds international study", Notes from Poland, June 25, 2020, https://notesfrompoland .com/2020/06/25/under-half-of-poles-say-homosexuality-should-be-accepted-butfigure-rising-finds-international-study/.

82 Pacewicz, P., and A.Ambroziak “Kaczyński do LGBT: „WARA od naszych dzieci!” I kto to mówi?", OKO.press, March 16, 2019, https://oko.press/kaczynski-do-lgbt-wara-odnaszych-dzieci-i-kto-to-mowi/.

83 Tilles, D. "Veganism is thriving in Poland — but faces a conservative backlash", Notes from Poland, November 15, 2019, https://notesfrompoland.com/2019/11/15/veganism-is-thrivingin-poland-but-faces-a-conservative-backlash/; Tilles, D. " 'Ecologism is very dangerous and contrary to the Bible', warns Polish archbishop", Notes from Poland, December 27 , 2019, https://notesfrompoland.com/2019/12/27/ecologism-is-very-dangerous-andcontrary-to-the-bible-says-archbishop-of-krakow/.
} 
communicates with "people" while circumventing the existing institutional framework of the state.

Based on the cases of PiS rhetoric on the Smolensk catastrophe, and its narratives on gender and anti-LGBTQ issues, I demonstrate how the latter could be used for political othering and for subverting the core democratic principles, including the human rights and freedom of expression. I critically analyze the conventional understanding of populism as a type of rhetoric (or ideology) juxtaposing "good people" against the "bad elite", which could be only produced by political parties. As Polish cases demonstrate, political parties, indeed, play a significant role in developing populist arguments, but other actors, such as Polish Catholic Church, civil activists, religious groups, etc., can successfully apply the populist rhetoric in their activities as well. Seen from PiS perspective, it is not only the "elite" but also different "others" (members of LGBT community, vegans, pro-abortion groups, those who reject the "Smolensk cult", etc.), who are viewed as the inimical opponents to the "good Polish people". This type of biopolitical rhetoric, in fact, reduces the complex issues of democratic politics to illiberal models, which became particularly visible due to the refugee crisis and Covid-19 pandemic.

These developments might herald further exclusion and erasure of the normative discourses indispensable for liberal democracies from the political realm. Russia represents a good example of how the logic of biopolitical othering gravitates towards totalization. Since the early 200os, Kremlin has been aggressively employing the biopolitical populism, replacing the classical idea of "people" (which is synonymous to the concepts of nation, citizenry, electorate and population) by the concept of "family" 84 ( which "re-establishes" the "people" on the basis of shared genetic memory and "blood bonds" 85 ).

Poland demonstrates similarity to Russia in cases of adoption, family and LGBTQ policies, culture wars related to re-interpretation of pivotal moments in national history, etc. However, PiS does not use the idea of family-even in the narrative on the Smolensk tragedy-as a replacement of the idea of people. ${ }^{86}$ This fact still underlines—at least partly—-the importance of the

84 Makarychev, A., and A. Yatsyk. The biopolitical turn in post-ideological times: a trajectory of Russia's transformation. In Kannike, A., Tasa, M., Västrik, E.-H. (eds) Body, Personhood and Privacy. Perspectives on Cultural Other and Human Experience. Approaches to Culture Theory 7. Tartu: University of Tartu Press, 2017), pp. 99-117.

85 Yatsyk, A. "Biopolitical conservatism in Europe and beyond: the cases of identity-making projects in Poland and Russia," Journal of Contemporary European Studies 27(4) (2019), p. 10.

86 Paluchowski, W. J. and K. Podemski "Mowy miesięcznicowe Jarosława Kaczyńskiego jako spektakl władzy," Ruch Prawniczy, Ekonomiczny i Socjologiczny 4 (2019), 253-268. 
democratic procedures in Poland today. In this context the populist actors react against all what they might perceive as diminishing role of sovereignty and national interests, and support the illiberal agenda of social conservatism. Both elements contain strong biopolitical components, which require further conceptualization.

Given the uncompromising position of the European Commission's newly elected President Ursula von der Leyen on the issue of the so-called "LG BTQfree zones", which she voiced during her first State of the Union Address on 16 September 2020, Poland under PiS is set for a collision course with the EU. ${ }^{87}$ This looming confrontation is likely to exacerbate both the domestic polarization in Poland and the use of biopolitical tools by PiS.

87 "President von der Leyen's State of the Union Address: charting the course out of the coronavirus crisis and into the future," an official website of the European Union, September 16 (2020), https://ec.europa.eu/commission/presscorner/detail/en/ip_2o_1657. 